\title{
INSTRUCTIONS TO AUTHORS
}

1. Papers for publication should be sent in triplicate to:

\author{
Peter TER BERG, Editor AB \\ Hildebrandhove 38, 2726 AW Zoetermeer \\ Netherlands.
}

Submission of a paper is held to imply that it contains original unpublished work and is not being submitted for publication elsewhere.

Receipt of the paper will be confirmed and followed by a referee process, which will take about three months.

2. Affiliation and address should be placed in a first footnote, which is not included in the count of the other footnotes.

Acknowledgements etc. should also be presented in this footnote.

Footnotes should be kept to a minimum.

3. Manuscripts should be typewritten on one side of the paper, double-spaced with wide margins.

4. Tables should only be included if really essential. Tables should be numbered consecutively. Do not use vertical lines!

5. Upon acceptance of a paper, any figures must be drawn in black ink on white paper in a form suitable for photographic reproduction with a lettering of uniform size and sufficiently large to be legible when reduced to final size.

6. Important formulae should be displayed and numbered on the lefthand side of the page. In mathematical expressions, especially in the text, authors are requested to minimize unusual or expensive typographical requirements. This may be achieved by using the solidus instead of built-up fractions and to write complicated exponentials in the form $\exp (\quad)$.

Matrices (uppercase) and vectors (lowercase) will be printed boldface. Boldface should be indicated by wavy underlining.

7. References in the text are given by the author's name in capitals, followed by the year of publication between parentheses.

Examples: RoTHENBERG (1973) has done . . . ; . . should be referred to FolKS and CHHIKARA (1978); . . . as shown by DE FINETTI (1937).

At the end of the paper the references should be grouped alphabetically and chronologically. For journal references give author(s), year, title, journal, volume and pages. For book references give author(s), year, title, city and publisher. Illustrated with the abovementioned references, this works out as:

FINETTI, B. DE (1937). La prévision, ses lois logiques, ses sources subjectives, Annales de l'Institut Henry Poincaré 7, 1-68. Reprinted as: Foresight: its Logical Laws, its Subjective Sources, in H. E. Kyburg and H. G. Smokler (Eds.) (1980). Studies in Subjective Probability. Huntington: Krieger Publishing Company, Inc.

FOLKS, J. L., and R. S. CHHIKARA (1978). The Inverse Gaussian Distribution and its Statistical Application - A Review (with Discussion), Journal of the Royal Statistical Society B 40, 263-289.

Rothenberg, T. J. (1973). Efficient Estimation with A Priori Information. New Haven: Yale University Press.

Observe that abbreviations should not be used! 


\section{COMMITTEE OF ASTIN}

$\begin{array}{rll}\text { Chairman: } & \text { Jürgen STRAUSS } & \text { West Germany } \\ \text { Vice-Chairman: } & \text { Harald BOHMAN } & \text { Sweden } \\ \text { Secretary: } & \text { Francis E. GUASCHI } & \text { Great Britain } \\ \text { Treasurer: } & \text { Jean LEMAIRE } & \text { Belgium } \\ \text { Editor: } & \text { Peter TER BERG } & \text { Netherlands } \\ \text { Members: } & \text { Hans BÜHLMANN } & \text { Switzerland } \\ & \text { Giovanna FERRARA } & \text { Italy } \\ & \text { Jean LAMSON } & \text { France } \\ & \text { Ragnar NORBERG } & \text { Norway } \\ & \text { Erkki PESONEN } & \text { Finland } \\ & \text { LeRoy J. SIMON } & \text { USA }\end{array}$

Neither the COMmITTEE OF Astin nor TIETO LTD are responsible for statements made or opinions expressed in the articles, criticisms and discussions published in ASTIN BULLETIN. 